\title{
Phomopsis Seed Decay of Soybean
}

\author{
Shuxian Li \\ United States Department of Agriculture-Agricultural Research Service \\ Crop Genetics Research Unit, Stoneville, MS 38776
}

USA

\section{Introduction}

Phomopsis seed decay (PSD) of soybean, Glycine max (L.) Merrill, is the major cause of poor seed quality in most soybean-growing countries (Sinclair, 1993). The disease is caused primarily by the fungal pathogen, Phomopsis longicolla, along with other Phomopsis and Diaporthe spp. PSD severely affects soybean seed quality due to reduction in seed viability and oil content, alteration of seed composition, and increased frequencies of moldy and/or split beans (Hepperly \& Sinclair, 1978; Rupe and Ferriss, 1986; Rupe 1990; Wrather at al., 2004). Hot and humid environmental conditions, especially during the period from the pod fill through harvest stages, favor pathogen growth and disease development (Balducchi \& McGee, 1987; Hartman et al., 1999).

PSD has resulted in significant economic losses (Baird et al., 2001; Hepperly and Sinclair, 1978). Losses on a worldwide basis were approximately 0.19 million metric tons (MMT) in 1994 (Kulik \& Sinclair, 1999). Effects of PSD on yields in the United States from 1996 to 2007 ranged from 0.38 to $0.43 \mathrm{MMT}$ (Wrather \& Koenning, 2009). In 2009, due to the prevalence of hot and humid environmental conditions from pod fill to harvest in the southern United States, PSD caused over 12 million bushels of yield losses in 16 states (Koenning, 2010).

\section{Disease symptoms}

Soybean seeds infected by $P$. longicolla or other Phomopsis spp. range from symptomless to shriveled, elongated, or cracked, and often appear chalky-white (Fig. 1). Infected seeds either fail to germinate or germinate more slowly than healthy seeds. Seed infection causes pre- and post-emergence damping-off, and under severe conditions, stands can be reduced to the point of lowering yield (Kulik \& Sinclair, 1999; Sinclair, 1993). Soybean pods can be infected at any time after they form. The fungi initially colonize seed coats, followed by colonization of the cotyledons and plumules. Mycelia invade the ovule and developing seeds through the funiculus and hilum. Within the seed, the fungi colonize all tissues of the seed coat and cotyledons, and eventually the radicle and plumule as well. (Kulik \& Sinclair, 1999).

Although $P$. longicolla is primarily known as a seedborne pathogen, it can be isolated from all parts of plant. It was the predominant species isolated from diseased plants collected from nine locations over a 3-year period in Canada (Xue et al., 2007). In another study, $P$. longicolla was the most frequently isolated fungal pathogen from both discolored and nondiscolored mature soybean stems (Harrington et al., 2000). It was also reported that $P$. longicolla was the major fungal species with the highest isolation frequency from all 


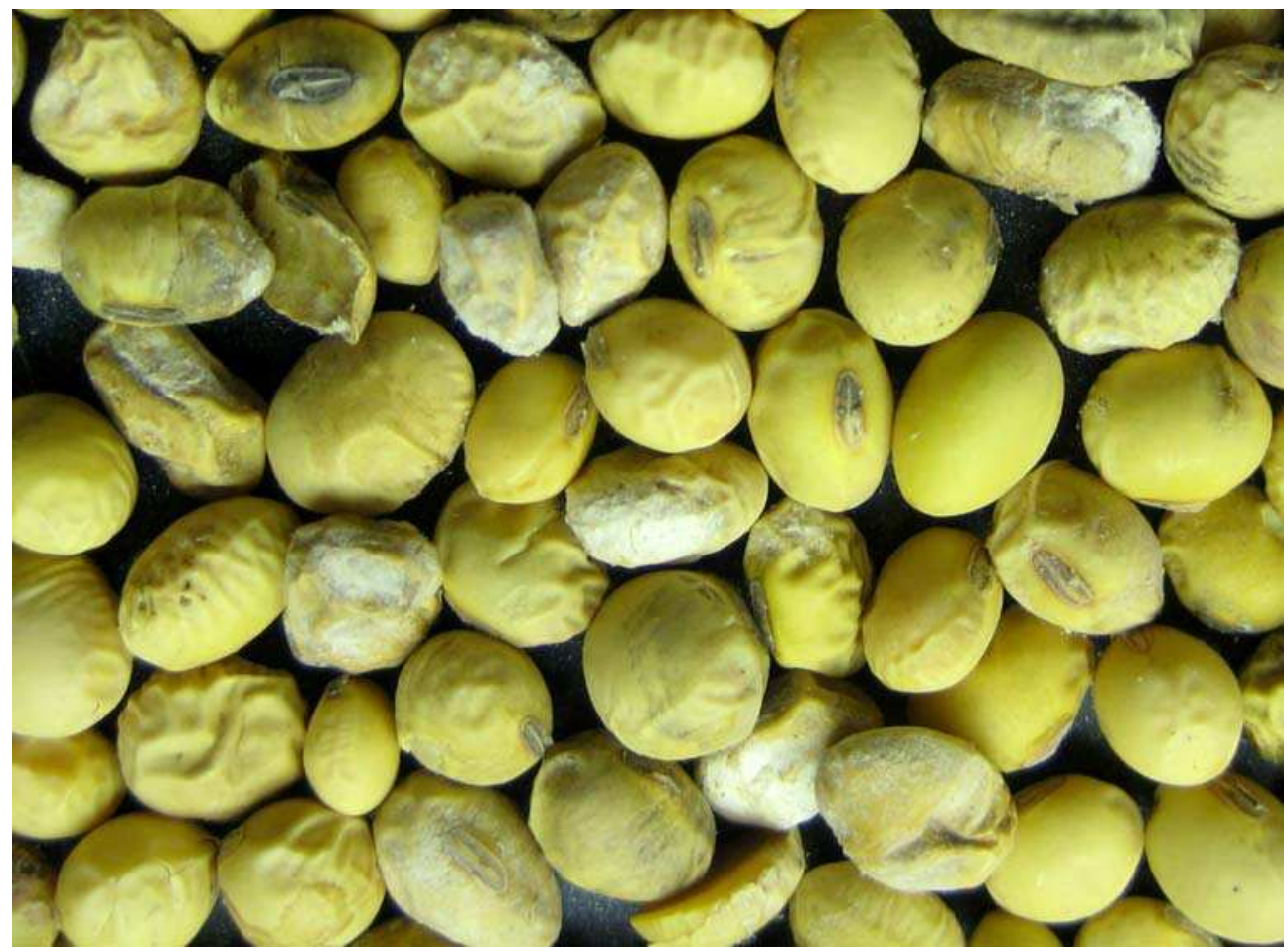

Fig. 1. Phomopsis seed decay caused primarily by the fungus Phomopsis longicolla.

vegetative plant parts, pods, and seeds in hot and humid environments over a 3-year period (Mengistu et al., 2009).

\section{The causal agents}

Species of the coelomycete genus Phomopsis (Sacc.) Bubák have been frequently isolated from different parts of host plants including seeds, stems, leaves and roots from a wide range of angiosperms, gymnosperms, and occasionally from bryophytes and pteridophytes (Farr et al., 1989). Over 65 species of Phomopsis have been reported as plant pathogens, and some of them cause severe diseases in economically important crops (Rehner and Uecker, 1994). Although PSD of soybean is caused primarily by Phomopsis longicolla T.W. Hobbs (Fig. 2), other Diaporthe and Phomopsis spp. have been found to be associated with the disease (Hartman et al., 1999; Sinclair, 1993).

\subsection{Diaporthe - Phomopsis complex}

The members of the Diaporthe - Phomopsis complex consist of P. longicolla and three varieties of Diaporthe phaseolorum (Cooke and Ellis) Sacc. (anamorph P. phaseoli (Desmaz) Sacc.), in which D. phaseolorum var. caulivora K. L. Athow and R. M. Caldwell, and D. phaseolorum var. meridionalis Fernández cause stem canker of soybean while D. phaseolorum var. sojae (S. G. Lehman) Wehmeyer causes pod and stem blight (Sinclair, 1993; 1999). The Diaporthe - 


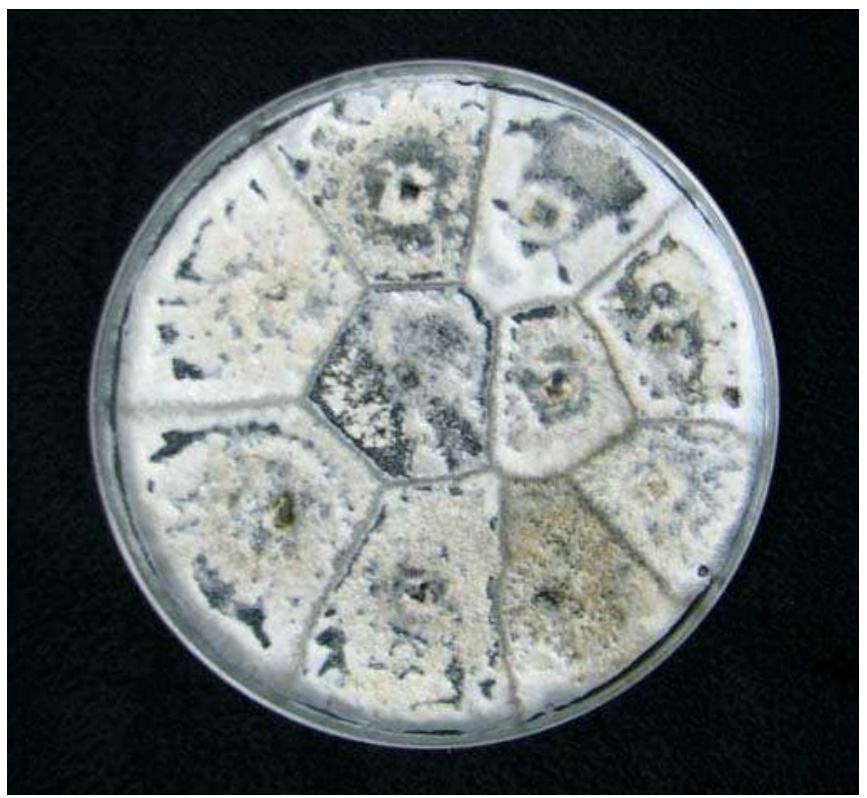

Fig. 2. Isolates of Phomopsis longicolla collected from Mississippi Delta in 2006 and grown on acidified potato dextrose agar ( $\mathrm{pH} 4.5)$ at $24^{\circ} \mathrm{C}$ for 20 days.

Phomopsis complex is distributed worldwide and causes more losses in soybean than any other single fungal pathogen (Sinclair, 1993). P. longicolla differs from others in the Diaporthe - Phomopsis complex in its morphology. It also does not have a known teleomorph (Hobbs et al., 1985). Although other Diaporthe and Phomopsis spp. may be associated with PSD, the disease is primarily caused by P. longicolla (Sinclair, 1993).

\subsection{Discovery and description of Phomopsis longicolla}

Phomopsis longicolla was first identified in 1985 (Hobbs et al., 1985). The majority of isolates used in that study were obtained as mycelial cultures from soybean seed, pod, and stem tissues collected from various locations in several states in the U. S. Hobbs et al. (1985) found that isolates used in their study could be divided into two groups based on colony appearance on potato dextrose agar (acidified to $\mathrm{pH} 4.5$ with $85 \%$ lactic acid) after being incubated under intermittent fluorescent light with a photoperiod of 12 hours daily for 2 weeks. Isolates from the first group clearly fit Lehman's (1923) description of P. Sojae and were always associated with a telemorph $D$. phaseolorum var. sojae. In contrast, isolates from the second group never formed perithecia. These isolates differed from Lehman's description of P. sojae, and from the isolates in the first group, in the shape of the pycnidial locule, the morphology of the conidiomata, the size and shape of the stromata, and in the conidiophore morphology (Hobbs et al., 1985). Hobbs et al. (1985) pointed out that isolates similar to the second group might have been observed in the past, but were probably reported as D. phaseolorum var. sojae. In addition, isolates in the second group were distinct from P. glycines and P. phaseoli Petch, the other Phomopsis species described from soybean. Based on the mophological differences and the pathological and ecological notes in reported 
studies (Kmetz et al., 1974; 1979), Hobbs et al. (1985) proposed that isolates similar to those in the first group retained the name of Phomopsis sojae, while isolates from the other group was described as a new species, Phomopsis longicolla. The description of $P$. longicolla by Hobbs et al. (1985) is as follows:

"Phomopsis longicolla Hobbs, sp. Nov.

Colonies on potato dextrose agar floccose, dense, white with occasional greenish-yellow areas; reverse colorless with large black stromata. Conidiomata pycnidial, black, stomatic, solitary or aggregated, unilocular or multilocular, with prominent necks more than $200 \mu \mathrm{m}$ long, opening by apical ostioles. Locules uniostiolate or multiostiolate, globose, up to $500 \mu \mathrm{m}$ wide. Conidiophores hyaline, simple or usually branched, septate, 3.5-24 x 1-4 $\mu \mathrm{m}$. Conidiogenous cells hyaline, filiform, phialidic. Alpha-conidia hyaline, ellipsoid to fusiform, guttulate, 5-9.5 x 1.5-3.5 $\mu \mathrm{m}$. Beta-conidia rare, hyaline, filiform, hamate. Isolated from seeds, pods, and stems of Glycine max (L.) Merr.; TWH P74 (BPI), Holotype, Hobbs, Wooster, Ohio, 13. XI.. 1983."

\subsection{Molecular detection and identification of the pathogens}

Because of the economic impacts of the PSD, accurate detection and identification of the PSD-causing pathogens are important for the development of the disease control strategies. The potato dextrose agar (PDA) seed-plating bioassay (Sinclair, 1982) is a common method used to identify causal fungi based on culture morphology. However, this traditional approach is very time-consuming and labor-intensive. Furthermore, the circumscription and identification of Phomopsis species using morphological and cultural characteristics is hampered by the plasticity of the characteristics. It was reported that in Phomopsis, morphological and cultural variation within single isolate may be as great as variation observed among isolates (Nitimargi, 1935; Parmeter, 1958). Serological assays, such as enzyme-linked immunosorbent assay (ELISA), also have also been used to detect PSD causal pathogens in plants and seeds (Brill et al., 1994; Gleason et al., 1987; and Velicheti et al., 1993). Due to insufficient specificity and sensitivity, the serological approaches are not used routinely in seed-testing laboratories. Molecular approaches, such as the polymerase chain reaction (PCR) and DNA sequencing are now commonly used to detect and identify fungal pathogens in plant tissues including soybean pathogens in soybean (Harrington et al., 2000; Li \& Hartman, 2003; Zhang et al., 1997).

Zhang et al. (1997) designed primers based on the sequences of nuclear ribosomal DNA that amplified the internal transcribed spacer (ITS) region of D. phaseolorum and P. longicolla. These primers could be used to specifically distinguish PSD-causal pathogens from each other and from other soybean fungal pathogens (Zhang et al., 1997). There were no differences in ITS sequences among seven geographically diverse isolates of $P$. longicolla (Zhang et al., 1998). Results from analysis of DNA from the Diaporthe - Phomopsis complex using PCR- restriction fragment length polymorphisms (PCR-RFLP) and DNA sequencing in the ITS and the 5.8 ribosomal DNA, along with morphological examination, indicated that $P$. longicolla is a distinct species, that $D$. phaseolorum var. caulivora and $D$. phaseolorum var. meridionalis are varieties of $D$. phaseolorum, and that $D$. phaseolorum var. sojae may either be several varieties of $D$. phaseolorum, or possibly several distinct species (Zhang et al., 1998).

\subsection{Aggressiveness of Phomopsis longicolla and other Phomopsis spp. isolates on soybean}

Knowledge about the variability of the pathogen is essential for understanding its population diversity, and such information will also be important for selecting isolates to 
develop broad-based disease resistance in soybean lines. However, there are only a few publications on the variability of aggressiveness on soybean among $P$. longicolla isolates. The term "pathogen aggressiveness", as used in this chapter, is based on colonization of and damage to soybean (Agrios, 1999; Shurtleff \& Averre, 1997).

Mengistu et al. (2009) reported that soybean pods inoculated at the growth stage R7 with two P. longicolla isolates from weeds showed $25 \%$ to $30 \%$ infection of seeds, while one soybean isolate caused seed infection of $80 \%$. Although the study used only a few isolates, the results indicated that there were real differences in aggressiveness between the isolates. In a recent study, $\mathrm{Li}$ et al (2010b) evaluated 48 isolates from the National Soybean Pathogen Collection Center at the University of Illinois at Urbana-Champaign. These included $35 P$. longicolla isolates from soybean in eight states in the U.S., along with the type culture of $P$. longicolla (Fau 600, ATCC 64802) from soybean in Ohio (Hobbs et al., 1985), two P. longicolla isolates from velvetleaf in Illinois (Li et al., 2001), and 11 other Phomopsis spp. isolates from other hosts in four states in the U.S., as well as from Canada and Costa Rica. Prior to the pathogenicity tests, each isolate of $P$. longicolla was examined for sporulation, dimension of conidia, pattern of stroma, and presence or absence of hyaline, filiform, and hamate beta conidia and perithecia to confirm identification (Hartman et al., 1999). The identifications of soybean isolates were verified previously by sequence analysis of the ITS regions and the mitochondrial small subunit rRNA genes (Li et al., 2001; Zhang et al., 1998). The identities of 11 other Phomopsis spp. isolates from other hosts were confirmed by the USDA-ARS Systematic Botany and Mycology Laboratory in Beltsville, MD (http://nt.ars-grin.gov/ fungaldatabases/specimens/specimens.cfm).

Evaluating isolates of seedborne pathogen for aggressiveness based on seed infecting characteristics are practically difficult, especially when working with many isolates. Since $P$. longicolla can be isolated from all plant parts, the cut-seedling assay measuring stem length and stem lesion length under controlled greenhouse conditions is, however, an easy and effective method to compare isolates and provide quantitative measurements of the infection by isolates on soybean. This method was used to test the pathogenicity of $P$. longicolla as a new pathogen on velvetleaf not only in the US (Li et al., 2001) but also in Croatia (Vrandecic et al., 2004), plus it was also used to confirm the first discovery of $P$. longicolla causing soybean stem blight in China (Cui et al., 2009). In the greenhouse pathogenicity tests conducted by Li et al. (2010b), aggressiveness of isolates of P. longicolla from soybean and other Phomopsis spp. from other hosts were compared by inoculating 2week old soybean plants of $\mathrm{cv}$. Williams 82 with them. There were significant $(P \leq 0.0001)$ differences among isolates based on stem length and stem lesion length. The $P$. longicolla soybean isolate PL16, from Mississippi, caused the shortest stem length while the nonsoybean isolate P9, from Illinois, caused the greatest stem lesion length. The type isolate of P. longicolla, PL31 (Fau 600), was one of the three most aggressive isolates among the 48 isolates evaluated. The velvetleaf isolate P9 from Illinois was the most aggressive among 13 isolates from non-soybean hosts. This study provided the first evaluation of aggressiveness of $P$. longicolla isolates from different geographic origins and the first demonstration that Phomopsis spp. isolated from cantaloupe, eggplant, and watermelon was able to infected soybean. This information is very useful for selecting isolates for screening in breeding broad-based resistance in soybean lines to PSD.

\section{Disease development and epidemiology}

PSD occurs in most soybean production areas, especially in the mid-south of the U.S. The incidence and severity of the disease vary year to year, particularly depending on the 
weather conditions (Wrather et al., 2003; 2004). Bradley et al. (2002) observed a greater percentage of harvested seed infection by Phomopsis spp. in most cultivars at Champaign, Illinois in 1999 than 1998. In the southern U.S., because of the drought stress commonly occurring during the bloom and pod fill stages, the Early Soybean Production System (ESPS) was developed to help growers avoid late-season drought damage to soybean (Heatherly, 1999). However, the ESPS creates a concern about seed quarlity because seed infection with Phomopsis spp. is high when early maturity cultivars are grown in the ESPS (Mayhew \& Caviness, 1994). A 3-year study was conducted to investigate the effects of planting date and cultivar on seed yield, quarlity, and Phomopsis sp. seed infection (Wrather et al., 2003). It was found that the incidence of PSD was frequently high and the seed quality low in seeds from early-maturing maturity group (MG) III and IV soybean cultivars planted in early- to midApril in the southern U.S. (Wrather et al., 2003). In another study conducted in 1995 to 1997 and in 2001 in the fields at Stoneville, Mississipi, significant effects due to year, irrigation, maturity group (MG), and date of planting (DOP) on the incidence of $P$. longicolla and seed germination were observed (Mengistu \& Heatherly, 2006). Irrigation treatment increased the levels of $P$. longicolla infection indicating that soil moisture could increase the relative humidity in the canopy in a way that favors PSD development. The incidence of PSD was also associated with total rainfall and rainfall frequency (Mengistu \& Heatherly, 2006).

\section{Disease management}

Several control strategies have been used to manage PSD and to reduce the impact of the disease. These include rotating soybeans with non-legume crops, such as corn or wheat, which are not hosts for the fungus, treating seeds with fungicides or applying fungicides during pod-fill, tilling the soil to disrupt spore dissemination, and harvesting mature seeds promptly. Along with these strategies, the use of resistant cultivars is the most effective method for controlling PSD (Jackson et al., 2005; Pathan et al., 2009; Roy et al., 1994), especially when environmental conditions are conducive for disease development.

\subsection{Screening for PSD resistance}

Screening soybean lines for resistance to PSD is the first step toward developing PSDresistant cultivars. A 3-year screening project begun in 2009 has been funded by the United Soybean Board (USB), a group of farmer-directors that administers the organization's soybean checkoff program, which seeks to strengthen soybean marketing, production technology, and research on new, value-added uses. In this project, hundreds of soybean germplasm accessions representing 28 regions or origins and from MG III to V, breeding lines, and commercial cultivars collected around the world were screened for resistance to PSD in three states (Arkansas, Mississippi, and Missouri) of the U.S. (Li et al., 2010a,c, \& d). Seeds, 33 seeds $\mathrm{m}^{-1}$ of row, were planted in 3.04-m long single row plots with a $0.96-\mathrm{m}$ row spacing. The experimental design was a randomized complete block with four replications. Seeds were harvested from each plot when the plants were mature. Seeds from each plot were tested for percent seed infected by Phomopsis spp., percent seed germination, and visual quality using a scale of 1 to 5 (Fig. 3) where $1=$ excellent (no bad/infected seed); $2=$ good (less than $10 \%$ bad/infected seed); $3=$ fair $(11-30 \%$ bad $/$ infected seed); $4=$ poor (31$50 \% \mathrm{bad} /$ infected seed); and $5=$ very poor (more than $50 \% \mathrm{bad} /$ infected seed). Factors considered in estimating seed quality were: seed wrinkling, molding, mottling, and discoloration. Frequent rainfall during seed maturation led to high levels of seed infection 
by a number of fungi (Fig. 4). Significant differences in seed infection by Phomopsis spp. were observed among soybean lines with some lines having no infection, while others had infection levels as high as $90 \%$. These differences between lines were also reflected in visual

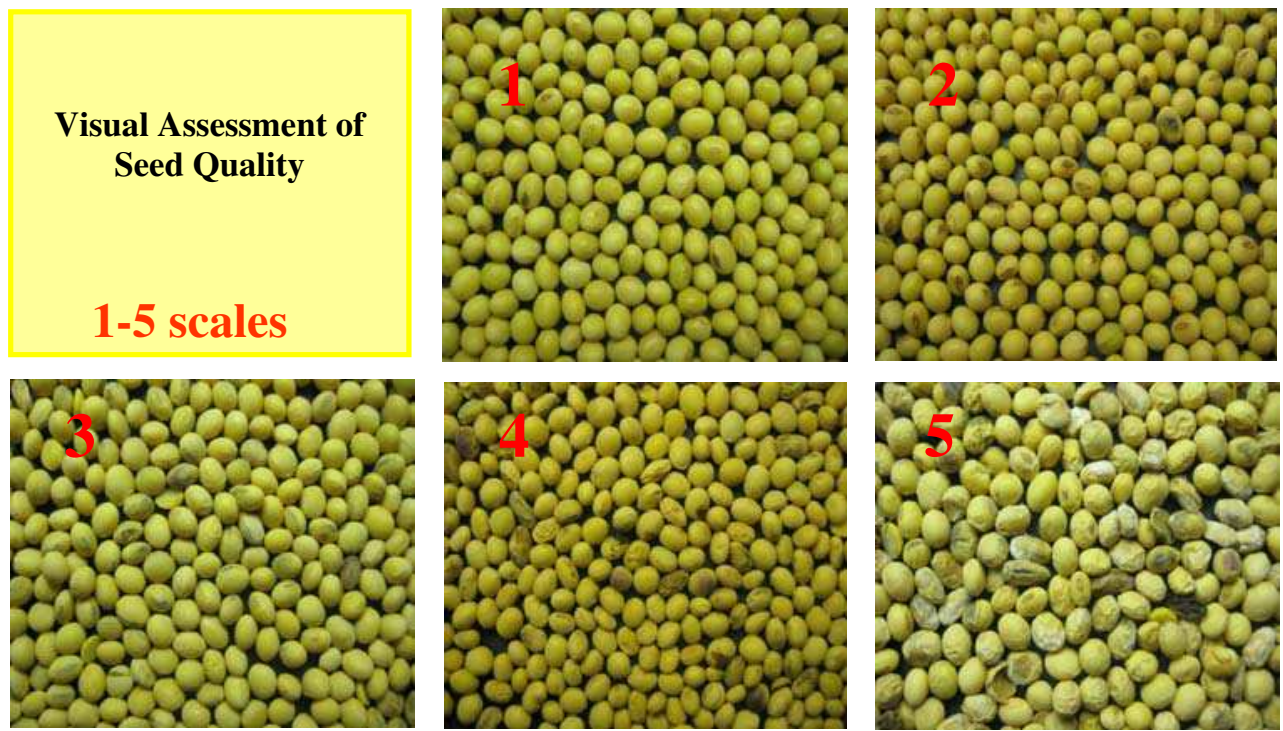

Fig. 3. Visual score of seed quality on a 1-5 scale, where $1=$ excellent seed (no bad/infected seed) and $5=$ very poor seed (more than $50 \%$ bad/infected seed).
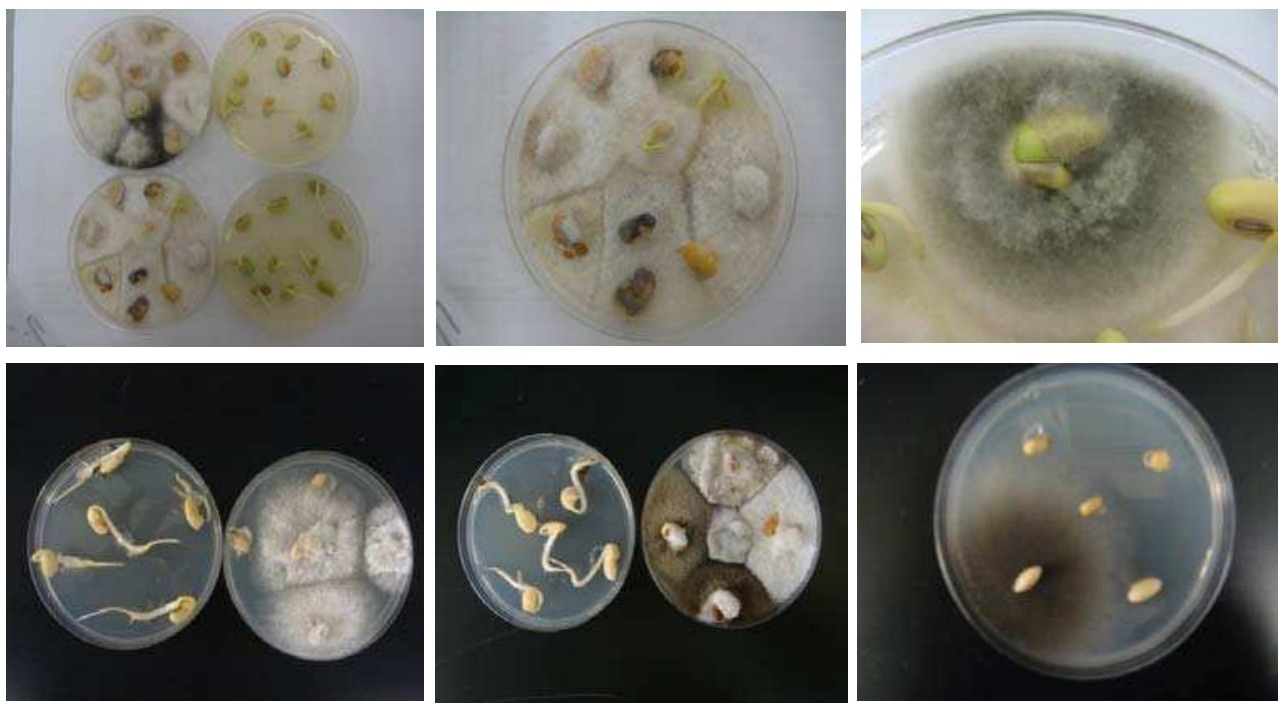

Fig. 4. Seed infection by a number of fungi were observed in the seed plating assays for the germplasm screening in United States in 2009 (Li et al., 2010 a,c, \&d). 
seed quality and seed germination (Fig. 5). Soybean lines with low infection incidences, good visual quality, and high germination rates at all locations were tested along with selected lines having differential responses to PSD cross locations in the 2010 field trials ( $\mathrm{Li}$ et al., $2010 \mathrm{a}, \mathrm{c}$, \& d). In addition, field screenings of over $200 \mathrm{MG} \mathrm{V}$ plant introductions were conducted in Stoneville, Mississippi, U.S. from 2006 through 2009 (Li et al., 2009b). Two potential PSD-resistant lines were identified ( $\mathrm{Li}$ et al., unpublished).
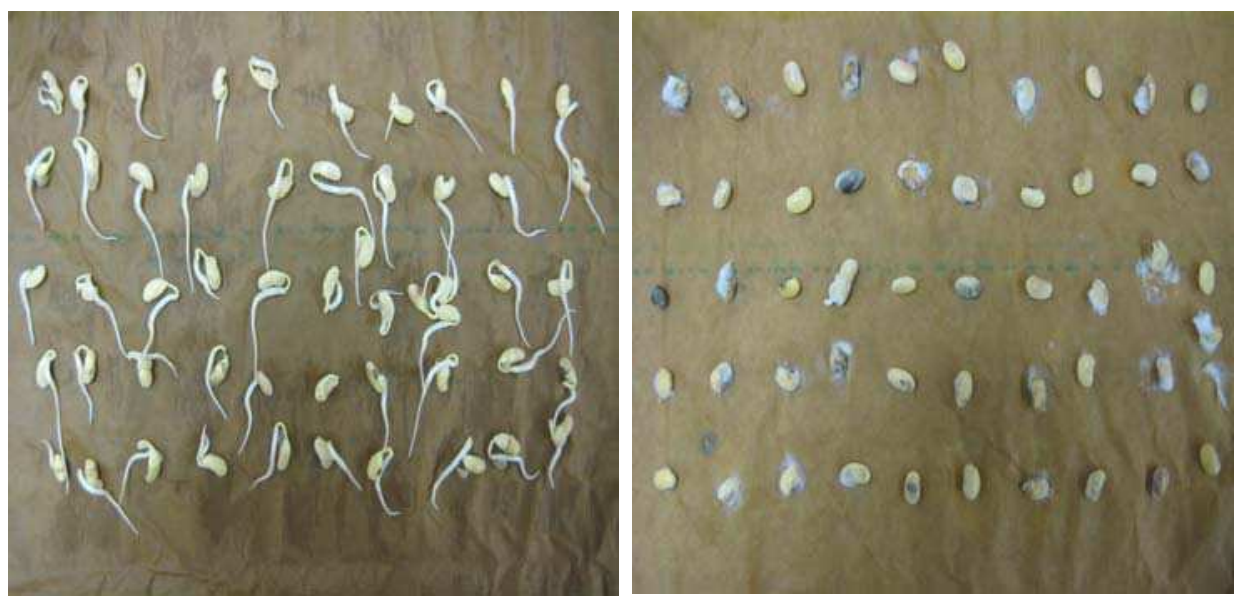

Fig. 5. Seed germination tests followed the protocol of Copeland, L. O. ed. (1981). The range of seed germination rates was from 10 to $100 \%$ for the assays of seed harvested from the germplasm screening in United States in 2009 (Li et al., 2010 a.c, \&d).

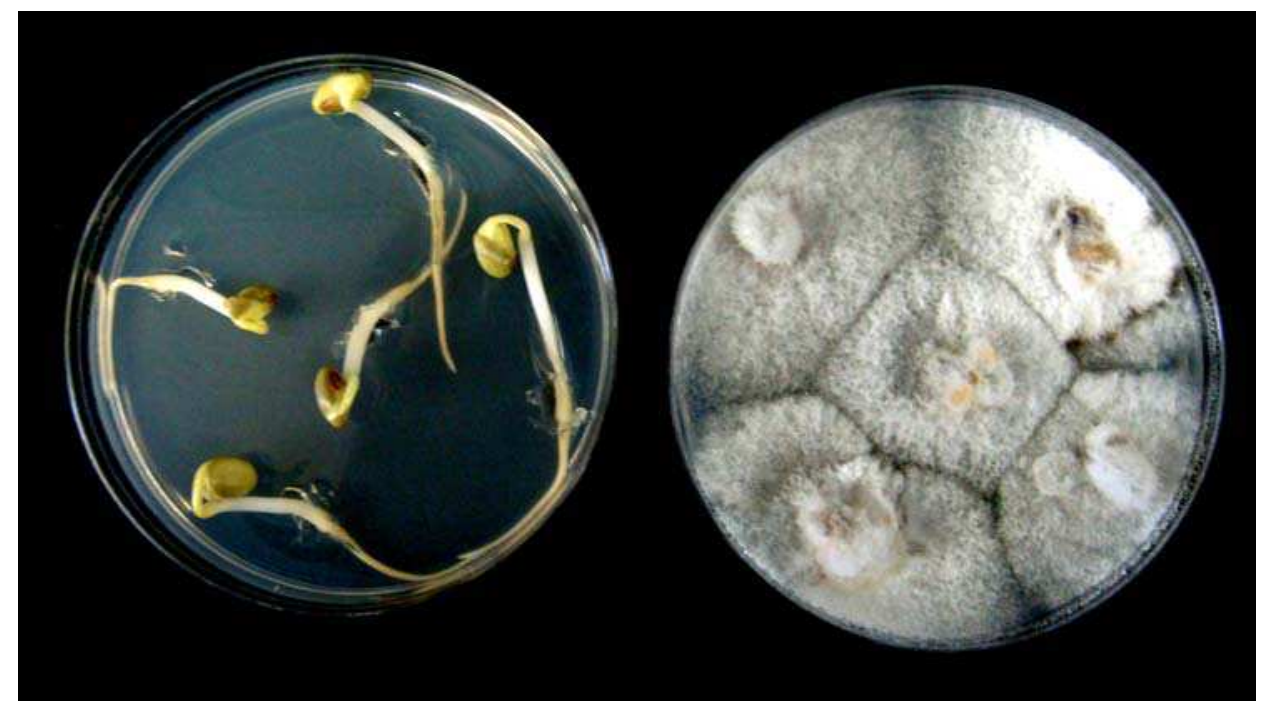

Fig. 6. Soybean lines without infection (left) and with high levels of Phomopsis spp. infection (right) were identified from the seed plating assay. 
In another screening project ( $\mathrm{Li}$ et al., 2009a), 50 soybean cultivars were planted at Stoneville, Mississippi to determine their reaction to PSD in 2007. Two lines, SS93-6012 and SS93-6181, previously reported to be PSD-resistant in Missouri were included, and the cultivars Hill and Williams 82 were used as susceptible checks. The seeds of soybean lines selected for planting were generally healthy. Of 50 lines tested, six lines had 100\% germination, 30 lines had germination rates ranging from $80 \%$ to $97 \%$, and 12 lines had rates ranging from $63 \%$ to $77 \%$. Two lines had germination rates of $50 \%$ and $53 \%$, respectively. In the seed plating assay, 37 lines had no $P$. longicolla-infected seed, 10 and three lines had $P$. longicolla incidences of $3 \%$ and $7 \%$, respectively. Incidence of $P$. longicolla in seeds from inoculated field plots differed significantly $(P \leq 0.05)$ ranging from $6 \%$ to $50 \%$ among soybean lines. Several soybean cultivars with lower disease incidence than the PSD resistant lines SS93-6181 and SS93-6013 were identified (Li et al., 2009a).

\subsection{Reported sources of PSD resistance}

Efforts have been made to identify sources of PSD resistance in the past decades. At least twenty-six soybean lines were found to have certain levels of PSD resistance (Table 1). However, some resistant lines identified in other regions were susceptible in Arkansas, Mississippi, or Missouri, U.S. (Li et al., unpublished). It is not known if there is "isolate by location" interaction, but there is a need to identify new sources of resistance to PSD.

\section{Inheritance of phomopsis seed decay resistance - case studies}

To date, inheritance of most reported sources of PSD resistance is still not clear. No gene symbol has been assigned for PSD resistance genes yet. However, there are some reports about the resistance to PSD characterized as qualitative and a number of major dominant genes (Jackson et al., 2005; 2009; Minor at al., 1995; Smith et al., 2008; Zimmerman \& Minor, 1993).

\subsection{Inheritance of resistance to PSD in soybean PI417479}

It was reported that PI 417479, a source of resistance to PSD, was identified by screening approximately 3,000 soybean introductions in MGs III and IV from 1983 through 1985 at the Agronomy Research Center of the University of Missouri, in Columbia, MO, USA and at the Isabela Substation of the University of Puerto Rico at Mayaguez ( Brown et al., 1987). To study the inheritance of PSD resistance in PI417479, crosses were made between PI417419 and each of two PSD-susceptible genotypes (Zimmerman \& Minor, 1993). By analyzing PSD incidence on plants from five generations $\left(F_{1}, F_{2}, F_{3}, B_{1}\right.$, and $B_{2}$, in which $B_{1}$ represented a backcross between the $F_{1}$ and the resistant parent and $B_{2}$ represented a backcross between the $F_{1}$ and the susceptible parents), it was concluded that the PSD resistance in PI417479 was controlled by two complementary dominant nuclear genes. The two resistance genes can thus be transferred using a backcross procedure (Zimmerman \& Minor, 1993).

\subsection{Inheritance of resistance to PSD in soybean PI80837 and MO/PSD-0259 (PI562694)} Ploper et al. (1992) identified PI 80837 having low levels of PSD infection in field trials in addition to its resistance to soybean mosaic virus and purple seed stain (Buss et al., 1979; Roy \& Abney, 1988; Wilcox et al., 1975). The PSD-resistant line MO/PSD-0259 derives its resistance from PI417479 (Jackson et al., 2005). To characterize the inheritance of PSD resistance in PI80837 and to determine if it differs from resistance in MO/PSD-0259, PI80837 


\begin{tabular}{|c|c|c|}
\hline & Soybean line & Reference \\
\hline 1 & PI548438 (Arksoy) & Minor et al., 1995 \\
\hline 2 & PI80837 & Brown et al., 1987 \\
\hline 3 & PI82264 & Walters \& Caviness, 1973 \\
\hline 4 & PI88264 & Minor et al., 1995 \\
\hline 5 & PI181550 & Athow, 1987 \\
\hline 6 & PI200501 & Ross, 1986 \\
\hline 7 & PI200510 & Minor et al., 1995 \\
\hline 8 & PI204331 & www.soydiseases.illinois.edu \\
\hline 9 & PI205089 & www.soydiseases.illinois.edu \\
\hline 10 & PI205907 & www.soydiseases.illinois.edu \\
\hline 11 & PI205908 & www.soydiseases.illinois.edu \\
\hline 12 & PI205912 & www.soydiseases.illinois.edu \\
\hline 13 & PI209908 & Minor et al., 1995 \\
\hline 14 & PI219635 & www.soydiseases.illinois.edu \\
\hline 15 & PI227687 & Minor et al., 1995 \\
\hline 16 & PI229358 & Minor et al., 1995 \\
\hline 17 & PI259539 & www.soydiseases.illinois.edu \\
\hline 18 & PI279088 & www.soydiseases.illinois.edu \\
\hline 19 & PI341249 & www.soydiseases.illinois.edu \\
\hline 20 & PI360835 & www.soydiseases.illinois.edu \\
\hline 21 & PI360841 & Brown et al., 1987 \\
\hline 22 & PI385942 & www.soydiseases.illinois.edu \\
\hline 23 & PI417419 & Brown et al., 1987 \\
\hline 24 & PI423903 & www.soydiseases.illinois.edu \\
\hline 25 & PI562694 & Minor et al., 1993 \\
\hline 26 & PI80837 & Ploper et al., 1992 \\
\hline
\end{tabular}

Table 1. A list of reported sources of resistance to Phomopsis seed decay. 
was crossed with each of the two PSD-susceptible lines Agripro 350 (AP350) and PI9113, and with MO/PSD-0259 (Jackson et al., 2005). Populations and lines were screened in the field and Phomopsis infection was assayed by plating seed. Seed infection of reciprocal $F_{1}$ plants of AP350 $\times$ PI80837 was not different from that of PI80837. Data from $\mathrm{F}_{2}$ populations of AP350 × PI80837 and PI91113 × PI80837; and F2:3 lines from AP350 × PI80837 fit models for a single dominant gene in PI80837 that confers PSD resistance. It was found that $F_{2}$ population data from AP350 $\times$ MO/PSD-0259 fit a model for single dominant gene resistance in $\mathrm{MO} / \mathrm{PSD}-0259$, and data from an $\mathrm{F}_{2}$ population and $\mathrm{F}_{2: 3}$ lines of PI80837 $\times$ MO/PSD-0259 fit a model for two different dominant genes. Based on those results, Jackson et al. (2005) concluded that PSD resistance in PI80837 is conferred by a single dominant gene under nuclear control that is different from the gene in MO/PSD-0259.

\subsection{Inheritance of resistance to PSD in soybean PI360841}

Studies on the inheritance of resistance to PSD in soybean PI360841 were conducted to test populations developed from the crosses between PI360841 and two PSD-susceptible genotypes, Agripro 350 (AP350) and P191113, to determine the number of genes for PSD resistance (Smith et al., 2008). Other crosses were made between PI360841 and the PSDresistant parents MO/PSD-0259 and PI80837 to test the allelic relationships of the resistance genes (Smith et al., 2008). Seeds from the parents and the $F_{2}$ population were assayed for Phomopsis infection. Chi-square analysis of F2 data from the resistant $\times$ susceptible crosses indicated a good fit to a 9R:7S model for two complementary dominant genes conferring PSD resistance in PI360841. $\mathrm{F}_{2}$ data from MO/PSD-0259 $\times$ PI360841 showed a good fit to a 57R:7S model for two complementary dominant genes from PI360841 and a different dominant gene from MO/PSD-0259. Since there was no apparent segregation for resistance in the $\mathrm{F}_{2}$ population derived from PI360841 × PI80837, except for one suspicious susceptible plant, it suggested that one of the genes in PI360841 is allelic to a PSD resistance gene in PI80837 (Smith et al., 2008). This was the first report of a new gene in PI360841 for PSD resistance. This gene, along with other different PSD-resistance genes in MO/PSD-0259 and PI80837 are useful to breeders for developing lines with a high level of resistance to PSD. Further studies have identified simple sequence repeat (SSR) markers linked to genes for PSD resistance in PI80837 and MO/PSD-0259. Jackson et al. (2009) reported that PSD resistance in MO/PSD-0259 and PI80837 is controlled by two different single dominant genes. The gene in PI80837 is located in the vicinity of Sat_177 (4.3 cM) and Sat_342 (15.8 cM) on molecular linkage group (MLG) B2 (chromosome 14). The gene that conditions resistance in MO/PSD-0259 is linked to Sat_317 (5.9 cM) and Sat_120 (12.7 cM) on MLG F (chromosome 13). Identification of these loci and markers linked to them will facilitate marker-assisted selection in breeding programs.

\section{Summary}

Phomopsis seed decay (PSD) of soybean causes poor seed quality and suppresses yield in most soybean-growing countries. The disease is caused primarily by the fungal pathogen Phomopsis longicolla along with other Phomopsis and Diaporthe spp. Infected seeds range from symptomless to shriveled, elongated, cracked, and often appear chalky-white. Seed quality is poor due to reduction in seed viability and oil content, alteration of seed composition, and 
increased frequencies of moldy and/or split beans. Hot and humid environments, especially during the period from pod fill through harvest, favor pathogen growth and disease development. The use of resistant cultivars is the most effective method for controlling PSD. Extensive screening for PSD resistance has resulted in the identification of resistant sources. MO/PSD-0259 carries a single dominant gene for PSD resistance derived from PI417479 whereas resistance in PI80837 is conferred by a different gene. PI360841 carries two complementary dominant genes for PSD resistance; both are different from the gene in MO/PSD-0259 but one of them maps to the same region as the gene in PI80837. Simple sequence repeat (SSR) markers linked to PSD resistance genes in PI80837 and MO/PSD-0259 have been identified. These SSR markers should be useful in selection for resistant genotypes in breeding programs.

\section{Acknowledgments}

The author appreciates the support of the United Soybean Board for the research project (\#9261) on Screening Germplasm and Breeding for Resistance to Phomopsis Seed Decay in Soybean as well as support from Drs. Pengyin Chen, John Rupe, and Allen Wrather for their collaboration with the project. Special thanks to Drs. Richard Joost, Stephen Muench, Lawrence Young, Jeff Ray, James Smith, David Walker, and Glen Hartman for valuable discussion about the research on Phomopsis seed decay. The author also thanks Drs. Richard Joost, David Walker, Houston Hobbs, and Xin-Gen Zhou for their thorough reviews of this book chapter. Mention of a trademark or proprietary product does not constitute a guarantee or warranty of the product by the U.S. Department of Agriculture and does not imply approval or the exclusion of other products that may also be suitable.

\section{References}

Agrios, G. N. (1999). Plant Pathology, Academic Press, San Diego, Califrornia, USA.

Baird, R. E., Abney, T. S., \& Mullinix, B. G. (2001). Fungi associated with pods and seeds during the R6 and R8 stages of four soybean cultivars in southwestern Indiana. Phytoprotection 82:1-11.

Balducchi, A. J., \& McGee, D. C. (1987). Environmental factors influencing infection of soybean seeds by Phomopsis and Diaporthe species during seed maturation. Plant Dis. 71:209-212.

Bradley, C. A., Hartman, G. L., Wax, L. M., \& Pedersen, W. L. (2002). Quality of harvested seed associated with soybean cultivars and herbicides under weed-free conditions. Plant Dis. 86: 1036-1042.

Brill, L. M., McClary, R. D., and Sinclair, J. B. (1994). Analysis of two ELISA formats and antigen preparations using polyclonal antibodies against Phomopsis longicolla. Phytopathology 84:173-179.

Brown, E. A., Minor, H. C. \& Calvert, O. H. (1987). A soybean genotype resistant to Phomopsis seed decay. Crop Sci. 27: 895-898.

Buss, G. R. Smith, T. J. \& Camper, H. M. (1979) Registration of Ware soybean cultivar. Crop Sci. 19: 564. 
Copeland, L. O. (1981) Rules for testing seeds. Association of official seed analysis, Stone Printing Co., Lansing, Michigan, USA.

Cui, Y. L. Duan, C. X., Wang, X. M., Li, H.J., and Zhu, Z.D. (2009). First report of Phomopsis longicolla causing soybean stem blight in China. Plant Pathol. 58:799.

Farr, D.F., Bills, G. F., Chamuris, G P. \& Rossman, A. Y. (1989). Fungi on plants and plant products in the United States. American Phytopathological Society Press, St. Paul, Minnesota, USA.

Gleason, M. L. Ghabrial, S. A. And Ferriss, R. S. (1987). Serological detection of Phomopsis longicolla in soybean seeds. Phytopathology 77: 371-375.

Harrington, T. C., Steimel, J., Workneh, F., \& Yang, X. B. (2000). Molecular identification of fungi with vascular discoloration of soybean in the north central United States. Plant Dis. 84:83-89.

Hartman, G. L., Sinclair, J. B., \& Rupe, J. C. (1999). Compendium of Soybean Diseases. $4^{\text {th }}$ ed. American Phytopathological Society, St. Paul, Minnesota, USA.

Heatherly, L. G. (1999). Early soybean production system (ESPS). In: Soybean Production in the Midsouth. L.G. Heatherly \& H.F. Hodges (Ed.) pp. 103-118 CRC Press, Boca Raton, Florida, USA.

Hepperly, P. R. \& Sinclair, J. B. (1978). Quality losses in Phomopsis - infected soybean seeds. Phytopathology 68:1684-1687.

Hobbs, T. W., Schmitthenner, A. F., \& Kuter, G. A. (1985). A new Phomopsis species from soybean. Mycologia 77:535-544.

Jackson, E.W., Fenn, P, \& Chen, P. (2005). Inheritance of resistance to Phomopsis seed decay in soybean PI80837 and MO/PSD-0259 (PI562694). Crop Sci. 45:2400 -2404 .

Jackson, E. W, Feng, C., Fenn, P, \& Chen, P. (2009). Genetic mapping of resistance to Phomopsis seed decay in the soybean breeding line MO/PSD-0259 (PI562694) and plant introduction 80837. J. Hered. 100: 777-783.

Kmetz, K.T., C.W. Ellett, \& A.F. Schmitthenner (1974). Isolation of seedborne Diaporthe phaseolorum and Phomopsis from immature soybean plants. Plant Dis. Reporter 58:978-982.

Kmetz, K.T., C.W. Ellett, \& A.F. Schmitthenner (1979). Soybean seed decay: sources of inoculum and nature of infection. Phytopathology 69:798-801.

Koenning, S. R. (2010). Southern United States soybean disease loss estimate for 2009. Proceedings of the Southern Soybean Disease Workers, the 37th Annual Meeting, p 1.

Kulik, M. M. \& Sinclair, J. B. 1999. Phomopsis Seed Decay. In: Compendium of Soybean Diseases. G. L. Hartman, J. B. Sinclair, \& J. C. Rupe (Ed.), Pp. 31 - 32 American Phytopathological Society, St. Paul, Minnesota, USA.

Lehman, S.G. (1923). Pod and stem blight of the soybean. Ann. Missouri Bot. Gara. 10:111-178.

Li, S., Bradley, C. A., Hartman, G. L. \& Pedersen, W. L. (2001). First report of Phomopsis longicolla from velvetleaf causing stem lesions on inoculated soybean and velvetleaf plants. Plant Dis. 85:1031.

Li, S., Boykin, D., Sciumbato, G., Wrather, A., Shannon, G., \& Sleper, D. (2009a) Reaction of soybean cultivars to Phomopsis seed decay in the Mississippi Delta, 2007. Plant Disease Management Rep., DOI: 10.1094/PDMR03: FC096 
(http://www.plantmanagementnetwork.org/pub/trial/PDMR/reports/2009/FC0 96.pdf). 2009.

Li, S., Chen P., Hartman, G. L., Smith, J. \& Nelson, R. (2009b). Research highlights on soybean Phomopsis seed decay in the US: pathogen characterization, germplasm screening, and genetic resistance. Abstracts of 2009 World Soybean Research Conference VIII (Beijing, China, August 10-15, 2009), pp. 91-92.

Li. S., Chen, P., Rupe, J., \& Wrather (2010a). Reaction of maturity group V soybean plant introductions to Phomopsis seed decay in Arkansas, Mississippi, and Missouri, 2009. Plant Disease Management Rep. 4: ST034.

Li, S., \& Hartman, G. L. (2003). Molecular detection of Fusarium solani f. sp. glycines in soybean roots and soil. Plant Pathol. 52:74-83.

Li. S., Hartman, L. G. \& Boykin, D. (2010b). Aggressiveness of Phomopsis longicolla and other Phomopsis spp. on soybean. Plant Dis. 94:1035-1040.

Li. S., Rupe, J., Chen, P., \& Wrather, A. (2010c). Reaction of maturity group IV soybean plant introductions to Phomopsis seed decay in Arkansas, Mississippi, and Missouri, 2009. Plant Disease Management Rep. 4: ST035.

Li. S., Wrather, A., Rupe, J., \& Chen, P. (2010d). Reaction of maturity group III soybean plant introductions to Phomopsis seed decay in Arkansas, Mississippi, and Missouri, 2009. Plant Disease Management Rep. 4: ST036.

Mayhew, W. L. \& Caviness, C. E. (1994). Seed quality and yield of early-planted, short season soybean genotype. Agron. J. 86: 16-19.

Mengistu, A., Castlebury, L. A., Smith, J. R., Ray, J. \& Bellaloui, N. (2009). Seasonal progress of Phomopsis longicolla infection on soybean plant parts and its relationship to seed quality. Plant Dis. 93:1009-1018.

Mengistu, A. \& Heatherly, L. G. (2006). Planting date, irrigation, maturity group, year, and environment effects on Phomopsis longicolla, seed germination, and seed health rating of soybean in the early soybean production system of the midsouthern USA. Crop Protection 25: 310-317.

Minor, H. C., Brown, E. A., \& Zimmerman, M. S. (1995). Developing soybean varieties with genetic resistance to Phomopsis spp. J. Am Oil Chem Soc. 72:1431-1434.

Nitimargi, N. M. (1935). Studies in the genera Cytosporina, Phomopsis, and Diaporthe. VII. Chemical factors influencing spore characters. Ann. Bot. (London), 49: 19-40.

Parmeter, J. R. (1958). An effect of substrate on spore form in Phomopsis. Phytopathology 48: 396-397. (Abstr.).

Pathan, M., S., Clark, K. M, Wrather, J. A., Sciumbato, G. L., Shannon, J. G., Nguyen, H. T., \& Sleper, D. A. (2009). Registration of soybean germplasm SS93-6012 and SS93-6181 resistant to Phomopsis seed decay. J. Plant Registrations 3: 91-93.

Ploper, L. D., Abney, T. S., \& Roy, K. W. (1992). Influence of soybean genotype on rate of seed maturation and its impact on seedborne fungi. Plant Dis. 76: 287-292.

Rehner, S.A. \& Uecker, F.A. (1994). Nuclear ribosomal internal transcribed space phylogeny and host diversity in the coelomycete Phomopsis. Can. J. Bot. 72:1666-1674.

Roy, K. W. \& Abney, T. S. (1988). Colonization of pods and infection of seeds by Phomopsis longicolla in susceptible and resistant soybean lines inoculated in the greenhouse. Can. J. Plant Pathol. 10: 317-320. 
Roy, K. W., Keith, B. C., \& Andrews, C. H. (1994). Resistance of hard seeded soybean lines to seed infection by Phomopsis, other fungi and soybean mosaic virus. Can. J. Plant Pathol. 16:122-128.

Rupe, J. C. (1990). Effects of temperature on the rate of infection of soybean seedlings by Phomopsis longicolla. Can. J. Plant Pathol. 12:43-47.

Rupe, J. C., \& Ferriss, R. S. (1986). Effects of pod moisture on soybean seed infection by Phomopsis sp. Phytopathology 76:273-277.

Shurtleff, M. C., \& Averre, C. W. III. (1997). Glossary of Plant-Pathological Terms. American Phytopathological Society, St. Paul, Minnesota, USA.

Sinclair, J. B. (1982). Seed testing: Detection of pathogens. In: Soybean Seed Quality and Stand Establishment. INSOY Ser. NO. 22. J. B. Sinclair and J. A. Jacobs (Ed.), pp. 112-115 University of Illinois, Urbana-Champaign, USA.

Sinclair, J. B. (1993). Phomopsis seed decay of soybeans - a prototype for studying seed disease. Plant Dis. 77:329-334.

Sinclair, J. B. (1999). Diaporthe - Phomopsis. Page 31 in: Compendium of Soybean Diseases. G. L. Hartman, J. B. Sinclair, and J. C. Rupe, eds. American Phytopathological Society, St. Paul, Minnesota, USA.

Smith, S., Fenn, P., Chen, P, \& Jackson, E. (2008). Inheritance of resistance to Phomopsis seed decay in PI360841 soybean. J. Heredity 99: 588-592.

Velicheti, R. K., Lamison, C., Brill, L. M., and Sinclair, J. B. (1993). Immunodetection of Phomopsis species in asymptomatic soybean plants. Plant Dis. 77: 70-73.

Vrandecic, K., Cosic, J., Riccion, L., Duvnjak, T., and Jurkovic, D. (2004). Phomopsis longicolla - new pathogen on Abutilon theophrasti in Croatia. Plant Pathol. 53:251.

Wilcox, J. R., Laviolette, F. A., \& Martin, R. J. (1975). Heritability of purple seed stain resistance in soybean. Crop Sci. 15: 525-526.

Wrather, J. A. \& Koenning, S. R. (2009). Effects of diseases on soybean yields in the United States 1996 to 2007. Online. Plant Health Progress doi:10.1094/PHP-2009-04401-01RS.

Wrather, J. A., Shannon, J. G., Stevens, W. E., Sleper, D. A. \& Arelli, A. P. (2004). Soybean cultivar and fungicide effects on Phomopsis sp. seed infection. Plant Dis. 88:721-723.

Wrather, J. A., Sleper, D. A., Stevens, W. E., Shannon, J. G. \& Wilson, R. F. (2003). Planting date and cultivar effects on soybean yield, seed quality, and Phomopsis sp. seed infection. Plant Dis. 87:529-532.

Xue, A. G., Morrison, M. J., Cober, E., Anderson, T. R., Rioux, S., Ablett, G. R., Rajcan, I., Hall, R., \& Zhang, J. X. (2007). Frequency of isolation of species of Diaporthe and Phomopsis from soybean plants in Ontario and benefits of seed treatments. Can. J. Plant Pathol. 29:354-364.

Zhang, A. W., Hartman, G. L., Riccioni, L., Chen, W. D., Ma, R. Z., \& Pedersen, W. L. (1997). Using PCR to distinguish Diaporthe phaseolrum and Phomopsis longicolla from other soybean fungal pathogens to detect them in soybean tissue. Plant Dis. 81:1143-1149.

Zhang, A. W., Hartman, G. L., Riccioni, L., Pedersen, W. L. \& Hartman, G. L. (1998). Molecular identification and phytogenetic grouping of Diaporthe phaseolrum and Phomopsis longicolla isolates from soybean. Phytopathology 88:1306-1314. 
Zimmerman, M. S. \& Minor, H. C. (1993). Inheritance of Phomopsis seed decay resistance in soybean PI417479. Crop Sci. 32:96-100. 


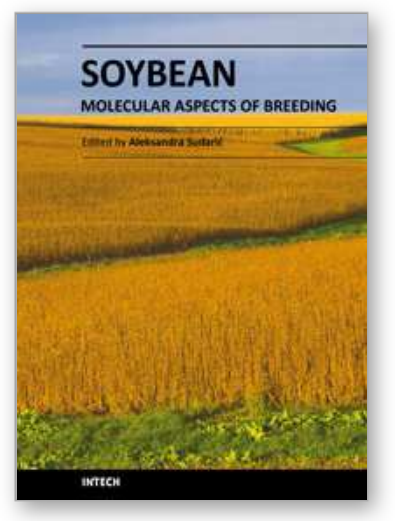

\author{
Soybean - Molecular Aspects of Breeding \\ Edited by Dr. Aleksandra Sudaric
}

ISBN 978-953-307-240-1

Hard cover, 514 pages

Publisher InTech

Published online 11, April, 2011

Published in print edition April, 2011

The book Soybean: Molecular Aspects of Breeding focuses on recent progress in our understanding of the genetics and molecular biology of soybean and provides a broad review of the subject, from genome diversity to transformation and integration of desired genes using current technologies. This book is divided into four parts (Molecular Biology and Biotechnology, Breeding for Abiotic Stress, Breeding for Biotic Stress, Recent Technology) and contains 22 chapters.

\title{
How to reference
}

In order to correctly reference this scholarly work, feel free to copy and paste the following:

Shuxian Li (2011). Phomopsis Seed Decay of Soybean, Soybean - Molecular Aspects of Breeding, Dr. Aleksandra Sudaric (Ed.), ISBN: 978-953-307-240-1, InTech, Available from: http://www.intechopen.com/books/soybean-molecular-aspects-of-breeding/phomopsis-seed-decay-of-soybean

\section{INTECH}

open science | open minds

\author{
InTech Europe \\ University Campus STeP Ri \\ Slavka Krautzeka 83/A \\ 51000 Rijeka, Croatia \\ Phone: +385 (51) 770447 \\ Fax: +385 (51) 686166 \\ www.intechopen.com
}

\author{
InTech China \\ Unit 405, Office Block, Hotel Equatorial Shanghai \\ No.65, Yan An Road (West), Shanghai, 200040, China \\ 中国上海市延安西路65号上海国际贵都大饭店办公楼405单元 \\ Phone: +86-21-62489820 \\ Fax: +86-21-62489821
}


(C) 2011 The Author(s). Licensee IntechOpen. This chapter is distributed under the terms of the Creative Commons Attribution-NonCommercialShareAlike-3.0 License, which permits use, distribution and reproduction for non-commercial purposes, provided the original is properly cited and derivative works building on this content are distributed under the same license. 